\title{
Crisis management communications for popular culture events
}

\begin{abstract}
The connection of popular culture with tourism lies on the activity of individuals to travel to specific destinations mainly because of popular culture, events and themes existing in these specific areas (Miller \& Washington, 2007). From a commercial perspective popular culture can be defined as mass culture for mass consumption including music, literature, sports, film, TV programs, drama, and pop-stars (Lee \& Bai, 2016). In terms of tourism marketing, several studies such as Kim et al. (2008) and Lee et al. (2008) highlight the positive influence of popular culture events on the formation of destination image. Still, popular culture may trigger negative perceptions for a destination if these events are not well organised or disastrous aspects appear (Gartner \& Shen, 1992), highlighting the importance not only for appropriate risk and crisis management but also the implementation of sufficient crisis communications.
\end{abstract}

Since tourism is considered as a prominent victim in crises (Vassilikopoulou et al., 2009), a destination's risk and crisis management capabilities should be of such quality that it can quickly resolve an evolving crisis and prevent it from spreading in (Racherla \& Hu, 2009) and create a considerable damage to its image. As Wilson and Anderson (2004) suggest, the ability to manage a crisis successfully can mean the difference between survival and disaster. As a result the competitiveness of a destination depends on its flexibility and its ability to change and adapt to the new reality (Papanond, 2007). Crises influence private agents' behaviour, decreasing the level of investment, export compositions, and consumption, and increasing uncertainty about future gains (Furceri \& Zdzienick, 2010). On the other hand, several strategies (i.e.: cost marketing reorientation; target markets' refocus; substantial use of Information Technology) have been suggested by researchers to help the destinations to survive when a crisis occurs (Papatheodorou \& Pappas, 2013). However, crisis management usually varies since the managers and stakeholders are likely to have different priorities and objectives, and may not perceive a crisis in the same way (Campiranon \& Scott, 2007). 
In popular culture events the audience should be used as the epicentre of crisis communications (Coombs \& Holladay, 2004) in an effort to minimise the negative perceptions produced from the crisis itself, and the parallel consequences to the destination and event image. According to Schwarz (2012), the crucial point is to provide an understanding of how publics cope with and interpret crises in order to develop a body of knowledge in crisis communications, from both critical and managerial/functionalist perspectives. Regardless the importance of popular culture events for destinations and their contribution to further tourism development, the literature is predominately silent concerning their risk and crisis marketing management and communications.

The aim of this study is to conceptually discuss the risk and crisis communication aspects in tourism with reference to popular culture events. It focuses on (i) the influence of potential crises in popular culture events on destination image and branding, (ii) the crisis marketing aspects that need to be considered from the event organisers and Destination Marketing Organisation (DMO) authorities, and (iii) the communications' reaction of stakeholders in respective crises. From a theoretical perspective, its contribution deals with the provision of an understanding in terms of marketing communications in popular culture events when facing crises. Managerially, this study contributes through the formulation of essential tools for crisis communications in the respective events, including both, external and internal marketing strategies.

\section{Related References}

Campiranon, K., \& Scott, N. (2007) Factors influencing crisis management in tourism destinations. In: E. Laws, B. Prideaux \& K. Chon. (eds.) Crisis management in tourism. (pp: 142-156) Wallingford: CABI.

Coombs, W. T., \& Holladay, S. J. (2004). Reasoned action in crisis communication: An attribution theory-based approach to crisis management. In: D. P. Millar, \& R. Heath (eds.), Responding to crisis. A Rhetorical approach to crisis communication (pp: 95-115). Mahwah, NJ: Lawrence Erlbaum.

Furceri, D., \& A. Zdzienick. (2010) The real effect of financial crises in European transition economies. Economics of Transition, 19(1), 1-25. 
Gartner, W.C., \& Shen, J. (1992). The impact of Tiananmen square on China's tourism image. Journal of Travel Research, 30(4), 47-52.

Kim, S.S., Agrusa, J., Chon, K., \& Cho, Y. (2008) The effects of Korean pop-culture on Hong Kong residents' perceptions of Korea as a potential tourist destination. Journal of Travel and Tourism Marketing, 24(2-3), 163-183.

Lee, S., \& Bai, B. (2016) Influence of popular culture on special interest tourists' destination image. Tourism Management, 52, 161-169.

Lee, S., Scott, D., \& Kim, H. (2008) Celebrity fan involvement and destination perceptions. Annals of Tourism Research, 35(3), 809-832.

Miller, R.K., \& Washington, K.D. (2007) The 2007 travel \& tourism market research handbook. Loganville, GA: Richard K. Miller \& Associates.

Papanond, P. (2007) The changing dynamics of Thai multinationals after the Asian economic crisis. Journal of International Management, 13(3), 356-375.

Papatheodorou, A. \& Pappas, N. (2013) The generating factors of crises in tourism and hospitality: Discussing the implications of the new era. $5^{\text {th }}$ International Scientific Conference “Tourism Trends \& Advantages in the $21^{\text {st }}$ Century”, $30^{\text {th }}$ May $-2^{\text {nd }}$ June, Rhodes, Greece.

Racherla, P., and C. Hu. (2009) A framework for knowledge-based crisis management in the hospitality and tourism industry. Cornell Hospitality Quarterly, 50(4): 561577.

Schwarz, A. (2012) How publics use social media to respond to blame games in crisis communication: The Love Parade tragedy in Duisburg 2010. Public Relations Review, 38(3), 430-437.

Vassilikopoulou, A., Siomkos, G., Chatzipanagiotou, K., \& Triantafillidou, A. (2009) Hotels on fire: investigating consumers' responses and perceptions. International Journal of Contemporary Hospitality Management, 21(7), 791-815.

Wilson, I., \& Anderson, A.R. (2004) Small tourist firms in rural areas: agility, vulnerability and survival in the face of crisis. International Journal of Entrepreneurial Behaviour and Research, 10(4), 229-246. 